\title{
PARAPERCIS GUSHIKENI, A NEW MUGILOID FISH FROM THE RYUKYU ISLANDS
}

$\operatorname{AUTHOR}(S):$

Yoshino, Tetsuo

\section{CITATION:}

Yoshino, Tetsuo. PARAPERCIS GUSHIKENI, A NEW MUGILOID FISH FROM THE RYUKYU ISLANDS. PUBLICATIONS OF THE SETO MARINE BIOLOGICAL LABORATORY 1975, 22(5): 343-346

ISSUE DATE:

1975-11-29

URL:

http://hdl.handle.net/2433/175895

RIGHT: 


\title{
PARAPERCIS GUSHIKENI, A NEW MUGILOID FISH FROM THE RYUKYU ISLANDS ${ }^{1}$.
}

\author{
Tetsuo YOSHINO \\ Department of Fisheries, Faculty of Agriculture, Kyoto University
}

With Text-figure 1

In 1971, a single specimen referred to the genus Parapercis was collected and photographed by Mr. Soko Gushiken of Okinawa Development Agency at Naha Wholesale Market. This specimen was offered me in compliance with my request. Since then, additional specimen was kindly sent to me by him and three specimens were collected by myself. Upon careful examination, these five specimens represent a new species, which is described and illustrated here.

A review of the genus Parapecis found in the waters of Japan was made by Kamohara in 1960. Subsequently, Cantwell (1964) and Schultz (1966 and 1968) made world-wide revisions and gave good keys. According to Cantwell (1964) and others, I adopted the family's name Mugiloididae instead of Parapercidae, the latter has often been used by Japanese ichthyologists.

In this report, the various counts and measurements were taken in the manner described in Cantwell (1964). The holotype and paratypes are preserved in 10\% formalin at the Seto Marine Biological Laboratory of Kyoto University.

\section{Parapercis gushikeni sp. nov.}

(New Japanese name; Wani-toragisu)

Holotype. SMBL (Seto Marine Biological Laborătory) F-73371, $300.5 \mathrm{~mm}$ in standard length, hooked by a hand line from one of banks off Okinawa I. (depth more than $100 \mathrm{~m}$ ), Ryukyu Is., May 1971.

Paratypes. SMBL F-73372, $297.2 \mathrm{~mm}$ in standard length, off Okinawa I., Ryukyu Is., Oct. 1971; SMBL F-73373 and 73374, 281.3 and 276.4 $\mathrm{mm}$ in standard length, off Okinawa I. (depth more than $100 \mathrm{~m}$ ), Ryukyu Is., Oct. 1972; SMBL F-73375, $241.2 \mathrm{~mm}$ in standard length, off Okinawa I., Ryukyu Is., June 11, 1973. Diagnosis

A big Parapercis with 8 or 9 dark streaks along longitudinal series of scales on upper half of body. Posterior margin of preopercle strongly serrated. Enlarged

1) Contributions from the Seto Marine Biological Laboratory, No. 608.

Publ. Seto Mar. Biol. Lab., XXII (5), 343-346, 1975,

(Article 24) 
caninelike teeth in outer row of lower jaw, 4 on each side. Vomer and palatines with villiform teeth. The third or fourth dorsal spine longest and the last one connected by membrane to the first ray. Middle rays of dorsal and pectoral fins elongated. Dorsal fin rays VI, 20. Anal fin rays I, 18. Pectoral fin rays 23 24 on each side. Pored scales in lateral line 58 60 .

\section{Description}

The following counts are recorded first for the holotype then for the paratypes: Outer enlarged teeth at front of lower jaw 8 and 8; dorsal fin rays VI, 20 and VI, 20; anal fin rays I, 18 and I, 18; pectoral fin rays 24 and $23 \sim 24$ (mostly 24); pored scales in lateral line 60 and $58 \sim 59$; scales from base of first anal ray to lateral line 13 and $12 \sim 14$; scales from anal opening obliquely backwards to lateral line 14 and $13 \sim 14$; zig-zag scales around caudal peduncle 29 and $28 \sim 29$; cheek scales 12 and $11 \sim 12$; gill rakers on first gill arch $5+11$ and $5 \sim 6+11$.

The following data are expressed in thousandths of the standard length, first for the holotype, then for the paratypes. Length of head 262 and $253 \sim 261$; length of snout 90 and $81 \sim 90$; diameter of eye 61 and 56 68; least width of interorbital 57 and $52 \sim 58$; distance from tip of snout to rear edge of maxillary 122 and $119 \sim 125$; least depth of caudal peduncle 113 and 107 112; greatest depth of body 219 and $171 \sim$ 209 ; length of the longest dorsal spine (3rd or 4th one) 96 and 106 111; longest pectoral ray 253 and $242 \sim 255$; longest pelvic ray 179 and $156 \sim 179$; longest caudal ray (middle one) 226 and $228 \sim 240$; length of dorsal fin base 622 and $632 \sim 662$; anal fin base 453 and $437 \sim 450$.

Body slender, cylindrical and gradually compressed backward; caudal peduncle strongly compressed; dorsal contour from tip of snout to origin of dorsal fin convex. Mouth large, oblique; upper jaw protractile; lower jaw slightly projecting beyond the upper when mouth closed. Maxillary concealed by the preorbital, extending below the anterior margin of pupil. Snout longer than the horizontal diameter of eye. Nostrils two, close together, and situated in front of eye; anterior nostril with an elevated rim and produced posterior conspicuous flap. Interorbital space rather wide and concave, a little less than the horizontal diameter of eye. Vomer and palatines with villiform teeth. Enlarged caninelike teeth in outer row near the tip of lower jaw, 4 on each side (mostly one or two come off). Tongue smooth, thick, round and free from the floor of the mouth. Preopercular margin strongly serrated, with some short broad-based spines at the angle. Opercle with a strong spine at upper part, the lower margin strongly serrated. Subopercle strongly serrated along posterior margin. Gill membranes free from one another and from the isthmus of the throat.

Dorsal fin originating slightly posterior above upper end of gill cleft. The third or fourth dorsal spine longest; spinous dorsal fin connected by membrane to the first ray of soft dorsal; soft dorsal higher than the spinous one; soft rays produced and the distal one third of longer rays extending beyond the membrane. Anal fin lower than the soft dorsal originating below fourth dorsal soft ray, consisting of one weak spine and eighteen branched soft rays. Pectoral with 23 to 24 rays, all branched 


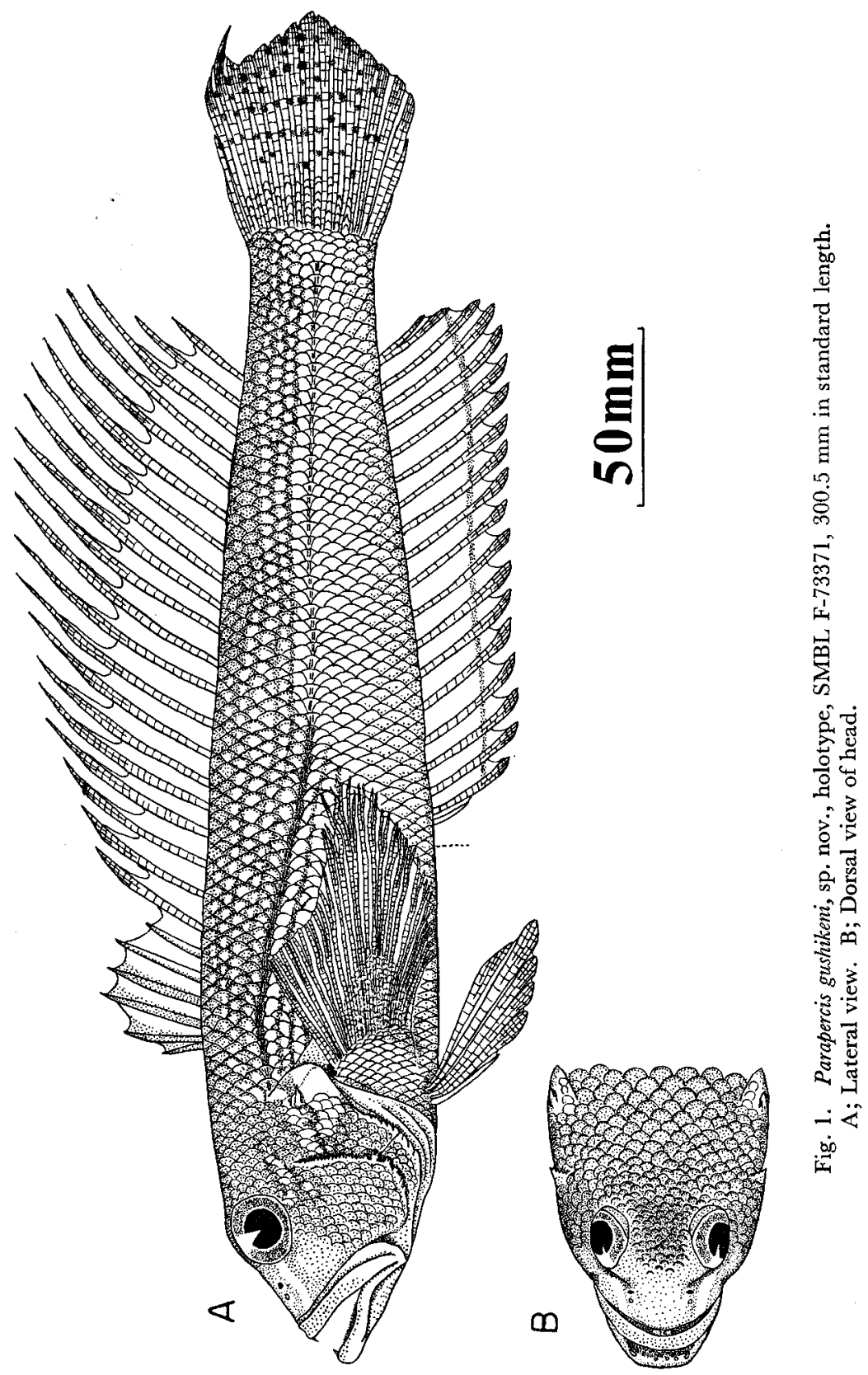

except for the uppermost one; middle rays produced, reaching to origin of the second anal ray; distal parts of the longer middle rays filamentous, extending beyond the membrane. Pelvic fin with one spine and five branched soft rays, inserted below the upper end of the gill cleft. Caudal fin shorter than the head, wedge-shaped, upper rays produced; the fin formula for branched rays $8+7$. 
Scales ctenoid; head scaled except for snout, preorbital, lips, maxillary, mandible, throat and posterior upper part of opercle; proximal parts of caudal and pectoral fins scaled; dorsal, anal and pelvic fins naked; head scales extending through interorbital space to the front border of the eye. Anterior part of lateral line above the pectoral fin convex; the posterior part almost straight, extending along middle of body.

Coloration. In life (from Kodachrome transparencies), body with 8 or 9 reddish brown streaks along longitudinal series of scales on upper half of body; interspaces of the streaks yellow; lower half of body whitish. Head reddish brown; a yellow stripe extending from snout to eye; side of head behind eye and opercle with several obscure yellow blotches. Spinous dorsal membranes margined with yellow anteriorly; soft dorsal with two longitudinal yellow streaks near the base. Distal part of anal fin with a longitudinal reddish streak. Caudal fin with 5 to 7 vertical rows of red spots; upper produced rays margined with white.

In formalin, body pale, the reddish brown streks remain. Yellow blotches and streaks of head and dorsal fin pale; a red streak of anal fin and spots of caudal fin indistinct.

Etymology

Species name is dedicated to Mr. Soko Gushiken who first collected the species. Remarks

The present new species is closely related to $P$. mimaseana (Kamohara) and $P$. striolata (Weber), in coloration, but it is easily distinguished from all known species of the genus in having constantly 6 dorsal spines ( 4 to 5 in other species) and higher number of pectoral fin rays (23 to 24 instead of 14 to 21 ). Separated gill membranes and filamentous pectoral fin rays are also peculiar characters in this species.

Acknowledgements

Mr. Soko Gushiken gave me important specimens. Dr. Osamu Okamura of Kochi University showed me unpublished data of Japanese mugiloid fish. Prof. Tamotsu Iwai of Kyoto University and Mr. Chuichi Araga of the Seto Marine Biological Laboratory gave me valuable informations. I am grateful to their courtesy.

\section{REFERENCES}

Beaufort, L.F. de and W.M. Chapman. 1951. The fishes of the Indo-Australian Archipelago, 9. Leiden, E.J. Brill., xi +484 pp., 89 figs.

Cantwell, G.E. 1964. A revision of the genus Parapercis, family Mugiloididae. Pacific Sci., 18(3): 239 280, 9 figs.

Kamohara, T. 1960. A review of the fishes of the family Parapercidae found in the waters of Japan. Repts. Usa Mar. Biol. Stat., 7(2): 1-13, 6 figs.

Schultz, L.P. 1966. Parapercis kamoharai (family Mugiloididae), a new fish from Japan with notes on other species of the genus. Smithonian Misc. Coll., 151(4): 1-4, $1 \mathrm{pl}$.

1968. Four new fishes of the genus Parapercis with notes on other species from Indo-Pacific area (family Mugiloididae). Proc. U.S. Nat. Mus., 124(3636) : 1-16, 4 pls.

Tomiyama, I. and T. Abe. 1958. Figures and descriptions of the fishes of Japan, 59. Kazama Shobo, Tokyo, pp. 1221-1247, figs. 594-598. 